\title{
Simulating land use change in the southern part of Warsaw Metropolitan Area with application of Dyna-CLUE model
}

PAULINA POKOJSKA

University of Warsaw, Faculty of Geography and Regional Studies, Warsaw, Poland; e-mail: ppokojska@uw.edu.pl

ABSTRACT The present research covers the issue of prediction of changes of the land use appearing due to progressing urban sprawl process in Piaseczno county, located in the Warsaw Metropolitan Area. The Dyna-CLUE land use change model was applied, assuming a variety of scenarios pertaining to the direction of change of land use within a time prospect of 20 and 35 years. The scenarios pertaining to the expected land use changes are developed with consideration given to the expected population changes. When implementing the Dyna-CLUE model, 8 factors having impact on the land use patterns within the research area are considered. As a result of the modelling, maps demonstrating the expected land use patterns have been created, making it possible to indicate municipalities and areas within which there is the highest probability of emergence of new buildings.

KEY WORDS land use modelling - land use changes prediction - urban sprawl - Dyna-CLUE model

POKoJSKA, P. (2019): Simulating land use change in the southern part of Warsaw Metropolitan Area with application of Dyna-CLUE model. Geografie, 124, 1, 57-82.

Received August 2017, accepted February 2019.

(C) Česká geografická společnost, z. s., 2019 


\section{Introduction}

Changes of the land cover are considered to be a relevant process, constituting an effect of the impact of the natural factors and of the ongoing socio-economic transformation. One of the processes which leads us towards changes of the land use is the suburbanization which in Poland has been one of the three most important directions of land use change, starting from the 1990s. (Poławski 2009).

The phenomenon of suburbanization in Poland before the year 1989 was virtually non-existent. Development and expansion of large cities had been a result of the urbanization process which had been directly correlated to the industrialization which in turn entailed spatial mobility of the people from the villages to large urban centres. Large cities within that period were being developed mainly through construction of housing estates, featuring numerous, multi-dwelling buildings (Beim 2007). After 1989 a deep socio-economic transformation has taken place. This led to emergence of the phenomenon known as suburbanization, a trend which is well known in the cities of the United States of America or the Western European states, and which is an unknown novelty, when it comes to the expansion of the largest Polish cities. Since the beginning of the 1990s, when as a result of the political transformation the housing and real property market became free, the land use structure in the suburban areas of large cities, including Warsaw, up until now undergoes as a result of the suburbanization process, intensive change.

Suburbanization in Poland is defined as vivid, uncontrolled and chaotic (Koncepcja 2012); it has been identified as a symptom of lack of spatial order at the local and regional levels and defined as economically and socially wasteful (Koncepcja 2012). It makes the process become a threat to the natural environment in the areas adjacent to the metropolitan area and this in a consequence creates numerous social conflicts at the local level. The phenomenon of suburbanization takes place within the zone adjacent to the administrative city limits, the width of which is defined as ca. 20-30 kilometers (Koncepcja 2012).

The pressure caused by "scattering" of the city over a larger area has an impact on the change of the land use in the metropolitan area, as agricultural area's surface is being decreased, which also leads to land development of the terrain which is valuable nature-wise (Grochowski 2009). The liberal spatial development model which is being implemented now means that no coordination exists when it comes to the spatial policy in large urban centres which, in turn, makes the displacement process related to the new housing tissue vivid and chaotic.

The National Spatial Development Concept predicts that by 2030 the population and business activity concentration process is still going too continue within the functional areas of large and medium cities, and within the surrounding rural areas (Koncepcja 2012), even despite the predicted trend of decrease, when it comes to the quantitative shape of the Polish population. 
Bański (2007) predicts that in the upcoming years the number of citizens of the villages adjacent to the cities is going to grow, same would apply to the villages located alongside the main communication routes. Moreover, Bański (2007) also predicts that in the nearest future spatial polarization processes concerning the rural areas may be amplified, with a division between the peripheral ones with hampered development or social degradation, and the ones adjacent to the large metropolises with the latter ones losing their rural character. The latter ones, without any doubts, include the Piaseczno county, which is the area of research in this paper.

Getting acquainted with the mechanisms and results of suburbanization is a must, because this process poses a threat for correct development of the functional metropolitan areas, their aesthetics and landscape harmony (Degórska, Deręgowska 2008). Suburbanization, as an unavoidable phenomenon, requires control and actions which could make it possible to fuse the housing and recreational, service- and transport related functions altogether (Zaktualizowana koncepcja 2005).

The aim of this work is to predict the changes of land use appearing due to progressing urban sprawl process within the suburban zone of the Warsaw Metropolitan Area. In the modeling, a model of land use change CLUE-S was applied. The Piaseczno county constitutes the area of the research (Fig. 1). It is located in the southern part of the Warsaw Metropolitan Area, it is one of the areas which was exposed to the most intensive suburbanization planning pressure in Poland, following the political transformation of 1989. In the light of the demographic

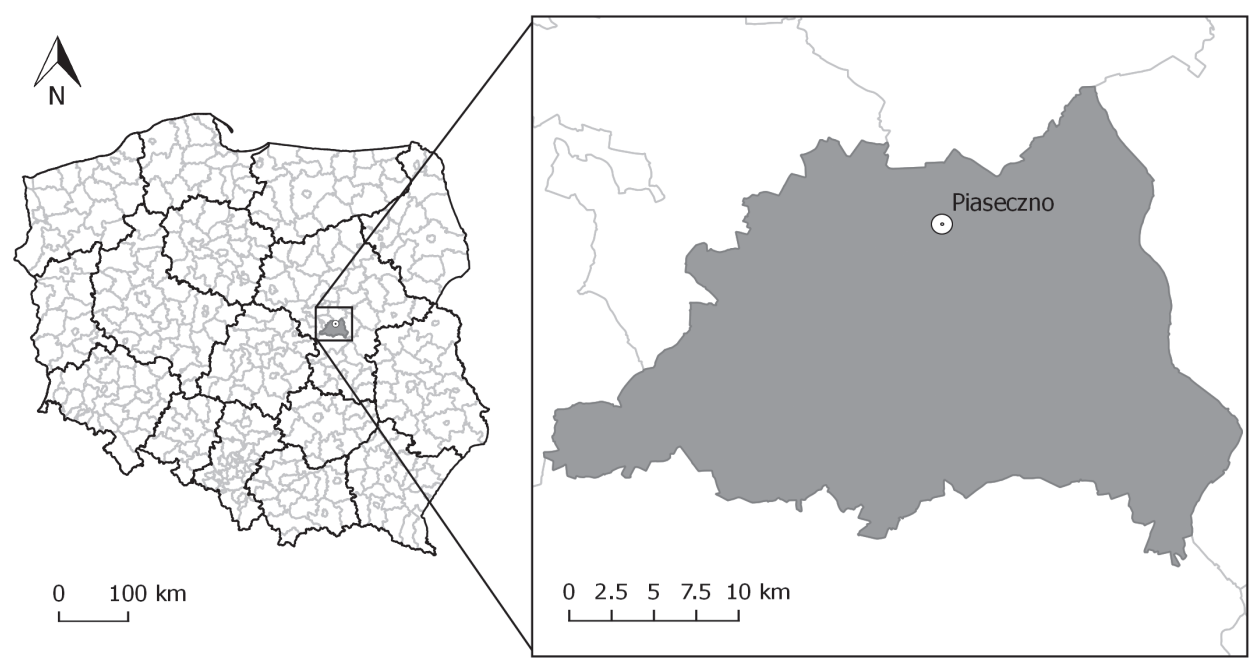

Fig. 1 - Research area 
forecast and projections presented in the further part of the present work, it is reasonable to suppose that the process of suburbanisation will continue.

Despite the number and complexity of the factors which have a decisive impact on the progress of suburbanization of this area, a hybrid Dyna-CLUE land use changes model has been selected to serve the analysis undertaken here.

Application of the mathematic model of change of the land use is one of the relevant methods which make it possible for us to get acquainted with the process of changes taking place within the scope of land use. Application of the model enables us to reveal and understand the mechanism of land use and to make predictions, also within the scope of the negative effect of those changes in connection with application of models of other phenomena.

\section{Urban sprawl modelling in Poland}

In Poland throughout the recent period several works have been written, covering the modelling process pertaining to the change of the land use. Nonetheless, the aforesaid research area still seems to be lacking attention. Świderski (2007), Beim (2007), Werner (2005, 2006, 2009), Werner, Korcelli, Kozubek (2014), Werner and Kozubek (2011), Litwińska (2010), Korcelli et al. (2012) have all been dealing with modelling the land use change in Polish cities, including the Warsaw Metropolitan Area, within the context of the urban sprawl phenomenon.

Świderski (2007) carried out a complex review of the land use models and has applied the CAM geoinformation-based model for land use change within the Poznan district, located in the western part of Poland. Beim (2007), on the other hand, applied a hybrid model which is a fusion of cellular automata and artificial neural networks, within the procedure of modelling the suburbanization process of the agglomeration of Poznan, covering the period between 1990 and 2005. Litwinska (2010) discussed the advantages provided by the cellular automata and allocation-transport model within the scope of the urban sprawl modelling. Werner $(2005,2006,2009,2012)$ and Werner and Kozubek (2011) applied the cellular automata for simulating land use change in the Warsaw Urban Area in 2025. Werner (2012) applied cellular automata model covering the whole territory of Poland, applying it within the period of 1969-2025, as well as for the selected metropolitan areas of Poland with use of the entropy formula (Werner, Korcelli, Kozubek 2014). Korcelli et al. (2012) applied the METRONAMICA ML model in simulating the land use in the Warsaw Metropolitan Area in 2025.

Due to the changes in the structure of land use in Poland, sometimes very intense (such as around some big cities as a result of urban sprawl), it is reasonable to undertake activities aimed at predicting changes in land use in the future using the latest techniques. Applications of mathematical models of land use change 
are still not frequent in Polish research, although, as it results from the review of the literature, there are more and more of them in the recent period. This work responds to the demand for work using mathematic models of land use change.

\section{Study area characteristics in the context of urban sprawl process}

Piaseczno county is located within the Warsaw Metropolitan Area and it covers an area of 621.04 sq. km (Fig. 1). Within the administrative dimension the county is divided into 6 municipalities including 4 city-rural municipalities (Góra Kalwaria, Konstancin-Jeziorna, Piaseczno, Tarczyn) and two rural municipalities (Lesznowola, Prażmów; Fig. 2). Piaseczno is the largest city and administrative unit within the county.

Agricultural areas are dominating (Fig. 3), when it comes to the land use structure ( $57.2 \%$ of the whole area of the county). Forests take up $22.5 \%$, housing structures constitute $11.4 \%$ of the area, while $3.3 \%$ is taken by the industry. The remaining $2.1 \%$ of the area is covered by the surface waters (Fig. 3). $20.3 \%$ of the total area is taken by housing developments within the most densely populated Piaseczno county. The least space is taken by the housing developments in the

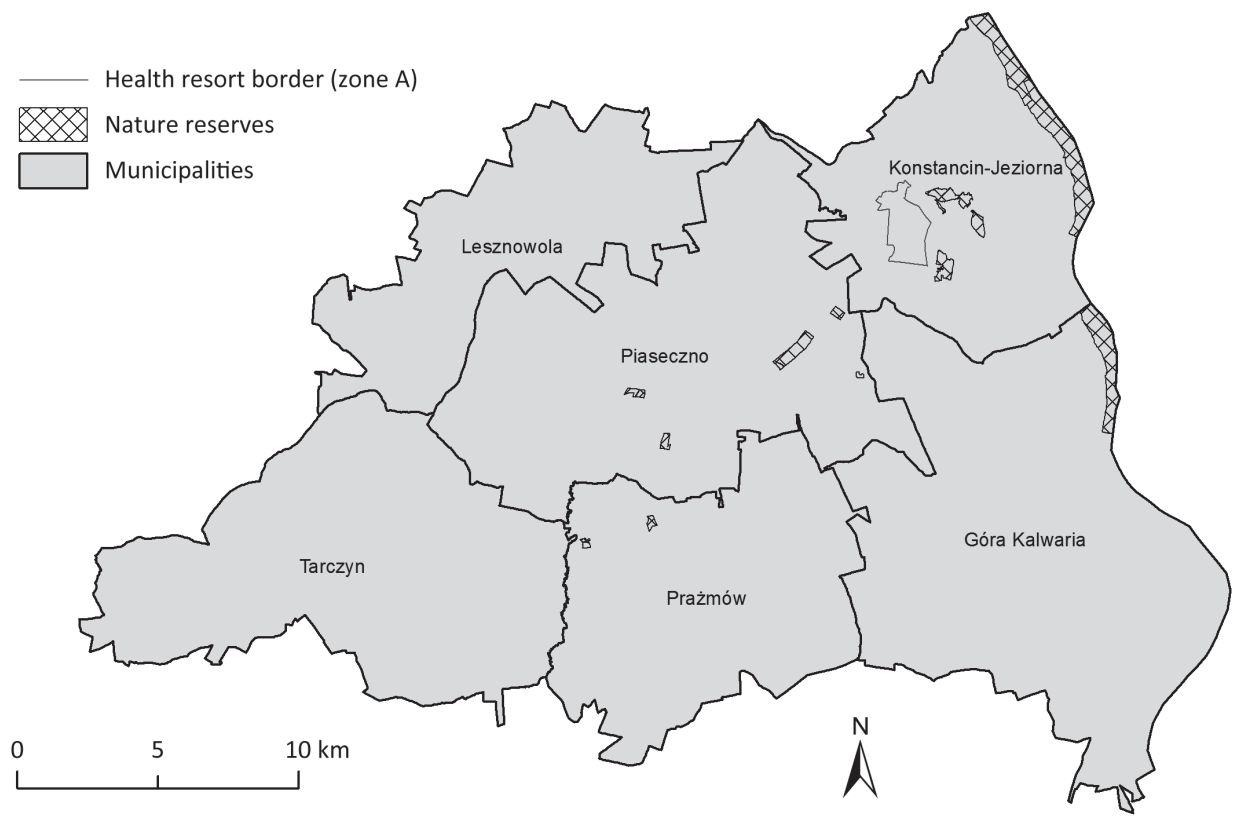

Fig. 2 - Administrative division of the research area with protected area 
county of Tarczyn, as the equivalent statistic there is defined as $6.33 \%$ (Table 1). Moreover, a variety of protected natural areas exist in the county including areas within which strict protection rules remain in force - among which 14 natural reserves exist (2.4\% of the total area of the county). Moreover, 3 healthcare (spa) protection zones exist, related to the Konstancin-Jeziorna spa, within the limits of which a special mode for creating buildings and investments is implemented.

The county, following the 1989 transformation, became a preferred direction for housing development in the Warsaw Metropolitan Area, even though no prospects of development had been seen there earlier (Mantey 2009a). The number of citizens living within the county throughout the last 15 years went up from 143 thousand in 2005 to 174 thousand in 2014. This had numerous consequences. Also, significant changes took place in numerous areas including the number of citizens within the demographic structure, functional significance of the researched areas in relation to Warsaw, land use structure, in the way in which people move or even in the degree of the specific character of their identity and connection formed in relation to the place of residence (Mantey 2013a).

Northern part of the county is undergoing an intensive suburbanization process, since it is located very close to the Warsaw's suburban zone, which reaches out 21 kilometers from the former municipality of Warsaw-Centre (Degórska, Deręgowska 2008). The municipality of Piaseczno located in the N part of the county, became one of the first Warsaw's suburban municipalities which began

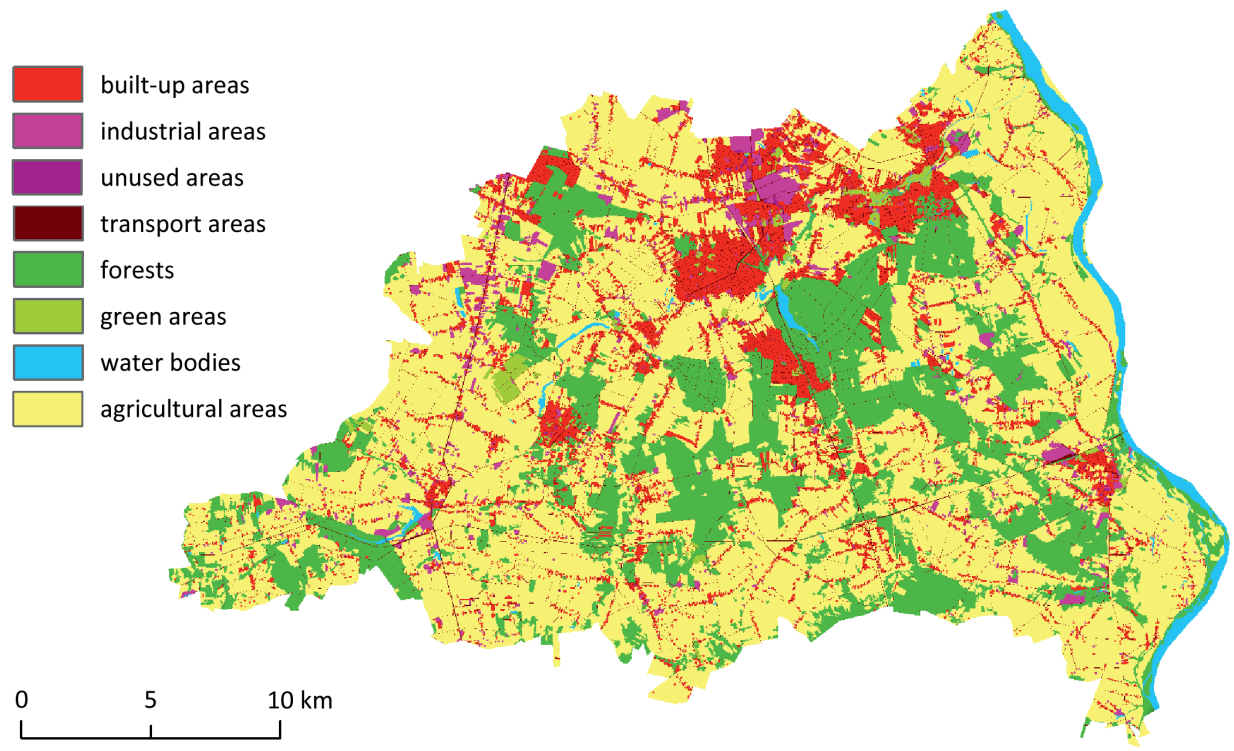

Fig. 3 - Land use in the research area 
Table 1 - Built-up and forest areas in particular municipalities in the Piaseczno county - current state

\begin{tabular}{lrrrrrr}
\hline Municipality & \multicolumn{3}{c}{ Area $\left(\mathrm{km}^{2}\right)$} & & \multicolumn{2}{c}{ Share of the total land area $(\%)$} \\
\cline { 2 - 3 } \cline { 6 - 7 } & Total & Built-up area & Forest & & Built-up area & Forest \\
\hline Lesznowola & 69.27 & 10.50 & 9.52 & & 15.16 & 13.75 \\
Prażmów & 86.46 & 7.19 & 23.39 & & 8.32 & 27.05 \\
Tarczyn & 114.08 & 7.22 & 22.54 & & 6.33 & 19.76 \\
Góra Kalwaria & 143.95 & 9.21 & 36.22 & & 6.39 & 25.16 \\
Piaseczno & 128.12 & 25.99 & 36.26 & & 20.29 & 28.30 \\
Konstancin & 78.50 & 10.71 & 11.66 & & 13.64 & 14.85 \\
\hline Total area of the county & 620.38 & 70.82 & 139.60 & 11.41 & 22.50 \\
\hline
\end{tabular}

to use its location and environmental features to develop housing estates (Mantey $2013 \mathrm{~b}$ ). Within the area of the municipality the buildings were placed more and more densely, alongside the communication routes, which is a direct consequence of the fact that Warsaw is a city which is largely based on automotive means of transport (Mantey 2009b). However, along with the passage of time, accessibility and time required to reach Warsaw became less dominant in their role for the persons migrating to the suburban zone. Natural environment, its attractiveness, and the general trend to live in the suburban area which would be close to the nature at the same time, became the main factors attracting the new citizens and which led to emergence of new buildings (Mantey 2009b). Among the new citizens of the villages located close to Warsaw a reversed, as compared to other suburban areas in Poland, hierarchy of factors exists, when it comes to the factors which are decisive within the scope of selection of the place of residence, as attraction factor group is far more important than the factors which would drive the citizens away from the given area (Mantey 2009c).

As a result of urbanization pressure imposed on the natural environment in the Piaseczno county, a number of detrimental phenomena were taking and are still taking place. In 3 municipalities (Piaseczno, Lesznowola i Góra Kalwaria) the total space taken by the forested areas has been significantly decreased (Degórska, Deręgowska 2008). Moreover, specific ecotone zones surrounding the forests disappear as a result of the fact that buildings are being located in the direct vicinity of the forests including, inter alia, the Kabacki Forest (Degórska, Deręgowska 2008). Closeness of the forest, which is an attractive factor for the potential inhabitants, simultaneously acts as a risk factor within the scope of degradation or even decline of the forested areas (Degórska, Deręgowska 2008). The urbanization pressure leads to degradation of the environmentally valuable regions, leading to scattering of those areas (Mantey 2009c). As Kozłowski (2006) suggests, the Mazowiecki and Chojnowski protected nature areas are seen as areas within which the natural environment is being "attacked". The areas which 
previously had been provided for planting a forest are being filled in with buildings, which is a result of withdrawal from the "green ring" concept, with a ring of forest which was to be surrounding the agglomeration, as authored by W. Plapis (Degórska, Deręgowska 2008).

The planning documents for the Piaseczno county (Strategia 2002) contain information suggesting that increased urbanization pressure imposed on the areas which have a high value environment-wise has been considered to be one of the primary threats for the natural environment. It was determined that this pressure is one of the causes for "limitation of important ecology-driven ties of a regional relevance", "significant devaluation of the ecologic zone at the limits of the forest- and meadow-areas, and forest- and field areas", degradation of minor and sensitive elements of the hydrographic network and limitation of the area, within which valuable soil is present. Too high level of dispersal of the buildings was said to be very worrying, as more technical infrastructure is required to maintain these buildings. Moreover, vast urbanized zone scattered from Konstancin-Jeziorna, through Piaseczno, Głosków to Złotokłos was also defined as a matter of concern, as this area divides the county into two environmentally isolated sections.

Within the typology of the municipalities located in the Warsaw Metropolitan Area, classifying them with attention paid to the landscape structure changes taking place between 2000 and 2004, 4 municipalities in the county of Piaseczno (excluding Konstancin-Jeziorna and Góra Kalwaria) have been classified as areas within which the landscape is undergoing the process of synanthropization (Degórska, Deręgowska 2008). Urban municipalities of Konstancin-Jeziorna and Góra Kalwaria are considered to be stable landscape-wise.

What is important, further, gradual growth of population is expected within the Piaseczno county; the forecast covering the period until 2050 assumes that a $44 \%$ increase shall be expected, as compared with the status present in the year 2014 (Prognoza 2015). In 2020, according to that forecast, the population is going to be as large as 189 thousand, 211 thousand in 2030, 229 thousand in 2040 and 247 thousand in 2050. In the light of the expected population growth one should also assume that further pressure would be imposed by the new buildings on the natural environment.

In the neighbourhood of Warsaw and other large cities fallowing of the agricultural land, "de-agriculturizing" that land or sales pertaining to this type of areas, are expected. It is also predicted that within the agglomeration of Warsaw and during the upcoming decades, internal deconcentration of population is still going to take place, as a result of the residential suburbanization process (Śleszyński 2014). It is also said within the forecast, that share of the urbanized areas within the whole area would be increased, with simultaneous decrease of the agricultural land and farmstead structures area (Degórska, Deręgowska 2008). According to 
the authors horizontal structure of the landscape and its changes in the Warsaw Metropolitan Area, especially in the rural areas, are going to be dependent on the distance of those areas from the Warsaw city centre. As the distance increases, the share of the urbanized areas would decrease, and the landscape would become synanthropized even more.

On the basis of the presented research (Degórska, Deręgowska 2008; Mantey 2013b, 2009c; Śleszyński 2014) a thesis may be formulated that in the light of the expected population growth, the new housing estates in the Piaseczno county are going to be created in the areas that are considered to be attractive, located close to the potential recreational areas, such as forests and open spaces. At the same time, the buildings would be erected as close to the city of Warsaw as possible, due to the time required to commute.

\section{Methods and data}

\subsection{Characteristics of Dyna-CLUE model and its applications}

Dyna-CLUE (Dynamic Conversion of Land Use and its Effects model) is a dynamic hybrid, empirical, multi-scale model, the purpose of which is to model the land use changes. It is a derivative of the CLUE model, enhanced and upgraded to the widely applied CLUE-s version. The model assumes that a simulation of competition among different land cover types for a particular location is carried out. Competition is expressed through the spatial allocation of demands for different land use types to individual grid cells.

The CLUE model has been developed back in 1996 for the purpose of simulating the land use changes within a grid occurring due to the impact imposed by biophysical and human drivers (Veldkamp, Fresco 1996). CLUE-s detailed derivative has been designed for modelling the land use changes in a more detailed, regional scale, such as watershed or province areas (Verburg et al. 2002) through introduction of homogeneous land use in each grid cell. Dyna-CLUE model is an adapted version of CLUE-s model, within which, besides the demand for land area, locally determined conversion processes have also been taken into account (Verburg, Overmars 2009).

Different versions of the model have been widely used in many regions around the world and they have been applied within a scale range from local (i.e. district of Kowloon with an area 8 sq. km, in Hong-Kong - Zheng et al. 2015) to continental (Europe - Verburg et al. 2006b, Verburg et al. 2010). The research areas include the natural terrain, such as islands, i.e. Sibuyan Island in Philiphines (Verburg et al. 2002), watersheds, i.e. Klang-Langat (Verburg et al. 2002), as well as administrative regions (i.e. five counties in Qinghai-Tibet Plateau in China (Liu et al. 2009) 
or protected areas (i.e. a part of the Northern Sierra Madre Natural Park in the Philippines (Verburg et al. 2006a).

Research with use of CLUE modelling approach was focused on a wide variety of issues: deforestation, land abandonment, agricultural intensification, urbanization and suburbanization. The CLUE-s and Dyna-CLUE model used for modelling the land use changes in the light of the urban sprawl phenomenon was applied as well by numerous researchers (Babaei Agdam, Ebraheemzade Asmin 2012; Batisani, Yarnal 2009; Chu, Lin, Wu 2010; Lin et al. 2008; Price et al. 2015; Roux, Augustijn 2015; Xavier 2013; Xu, Song, Yin 2013).

The present study makes use of the Dyna-CLUE model (Verburg, Overmars 2009), shared by the Institute of Environmental Studies, VU University Amsterdam (Verburg 2010).

\subsection{Structure of the model Dyna-CLUE and its adaptation to the research area}

Modelling with the use of the Dyna-CLUE model is carried out in two stages. First non-spatial stage assumes that a logit analysis is used as a basis for determining the factors governing particular classes of land use in a given area. The second spatial stage, during which the procedures are being carried out with the application of the initial land use map, assumes that a simulation of change of land use is executed, with a particular focus given to 4 groups of information:

1. Logit regression parameters for each of the statistically relevant driving factors.

2. Land use requirements expressed as a land use demand for each form of land use.

3. Restrictions and spatial policy (areas excluded from land use change).

4. Rules of land transformation (conversion elasticity, land use transition sequences).

Each pixel contained within the map is then a part of the computing process, involving the probability of transformation of the existing land use form into another form. The conversion is carried out in a way which allows us to reach the form which has the highest probability of emerging within the given location. Total probability of emergence of the given land use form within the given grid cell is calculated in line with the following formula (Verburg, Overmars, 2009):

Ptot $_{i, t, l u}=$ Ploc $_{i, t, l u}+$ Pnbh $_{i, t, l u}+$ ELAS $_{l u}+$ Comp $_{t, l u}$

Where:

Ptot $t_{i, t}, l u$ - total probability of emergence of the given land use form within the grid cell which is the subject of computations; this probability is computed for all of the usable areas which are to be included in the conversion process. 
Ploc $i, t, l u$ - suitability of the given location (i cell) for the given land use $u$ form (estimated on the basis of the logistic regression between the land use and the driving factors).

$P_{n b h}, t, l u$ - suitability of the given location, estimated on the basis of the analysis of the neighbouring areas - activating this option within the model is optional.

$E L A S_{l u}$ - conversion elasticity, characterizing the land use form which is being present within the relevant cell

Compt, lu - iteration of competitiveness variable for the given land use form.

The total quantity of grid cells within the research area which are to be transformed (spatially allocated) into a new use form is, within the further iteration, confronted against the land demand concerning each of the land use categories, and then ultimately tailored to that demand. Areas defined as restricted are excluded from the conversion, while total suitability of the given location for the new form of land use is influenced by the logit regression factors, defining the driving factors' impact and the defined parameter values: conversion elasticity, representing the costs of transformation of the existing land use form and land use transition sequences which define the possible transitions and potential speed and spatial limitations for such transition. Within the modelling process, neighbourhood analysis may also be taken into account. In our case, this stage was dismissed.

For the purpose of implementing the Dyna-CLUE model, 8 driving factors of 2 groups have been selected: physical-geographic and socio-economic ones. The factors were selected based on a review of the literature on changes in land use (Verburg et al. 1999, Briassoulis 2009), and their modelling (Verburg, van de Steeg, Schulp 2005), research area and urban sprawl in this area (Mantey 2009a, b, c; Mantey 2013a, b; Degórska, Deręgowska 2008), as well as planning documents of the Piaseczno county (Strategia 2002). The factors considered important in the processes of land use change in the Piaseczno county include:

- Within the physical-geographical factors group: types of the surface formations, distance from the surface waters, distance from the forest areas.

- Within the socio-economic factors group: distance from the Warsaw city limits, distance from other buildings, distance from the shopping malls, distance from the railway stations, distance from the Warsaw access roads (Fig. 4). Due to some unpredictability of changes of socio-economic factors, included in the study, it was assumed that the independent variables in the modeling will be stable.

Binominal logit regression was applied, so that it would be possible to determine the relationships between the individual driving factors (independent variables) and subsequent land use forms (dependent variables), and to indicate the statistically relevant factors for each land use class (Table 2). The basis for considering the impact of the driving factors on the spatial distribution of the given land use forms 


\section{Distance from main roads}

\begin{tabular}{|l}
\hline $0-1$ \\
$1-2$ \\
$\square$ \\
$2-3$ \\
$\square>3 \mathrm{~km}$
\end{tabular}

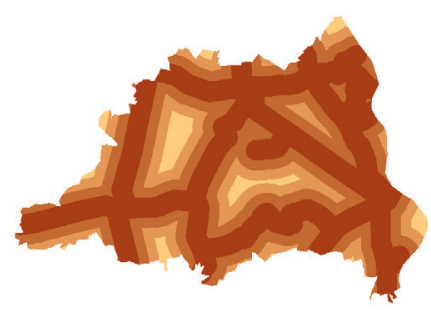

Distance from train stations

\begin{tabular}{l}
\hline $0-5$ \\
$5-10$ \\
$10-15$ \\
$15-20$ \\
$>20 \mathrm{~km}$ \\
$\square$
\end{tabular}

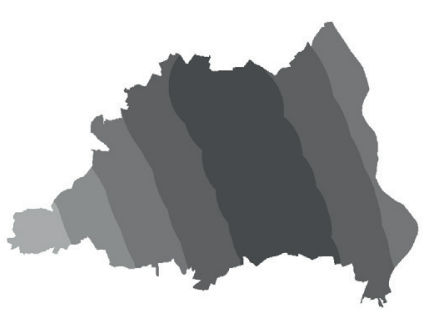

\section{Distance from buildings}

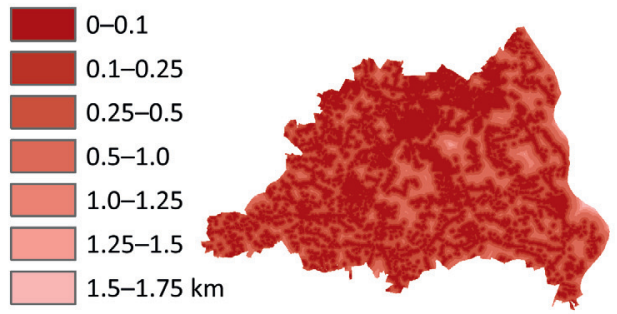

\section{Soils}

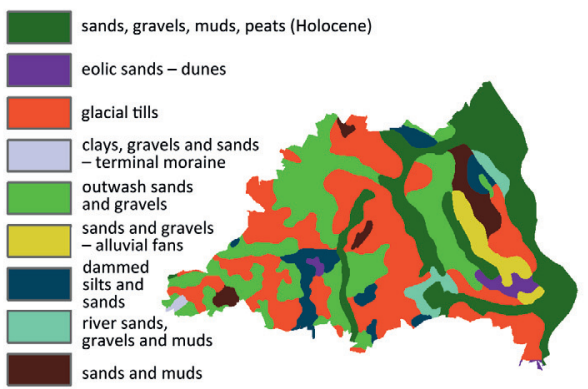

\section{Distance from border of Warsaw}

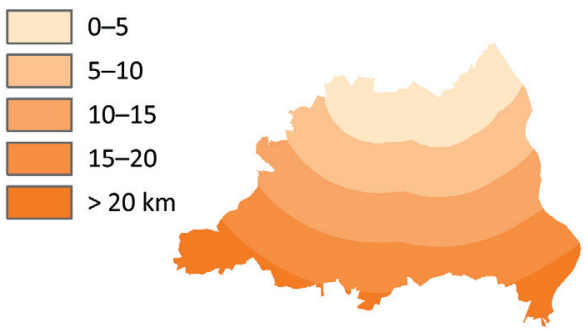

Distance from forests

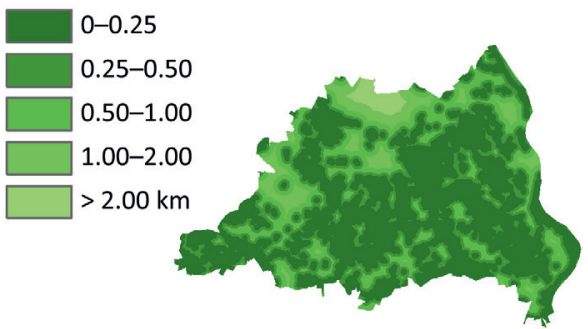

Distance from shopping centres

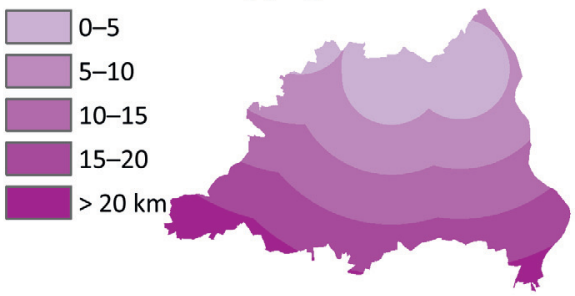

Fig. 4 - Spatial distribution of land use driving factors in the research area 


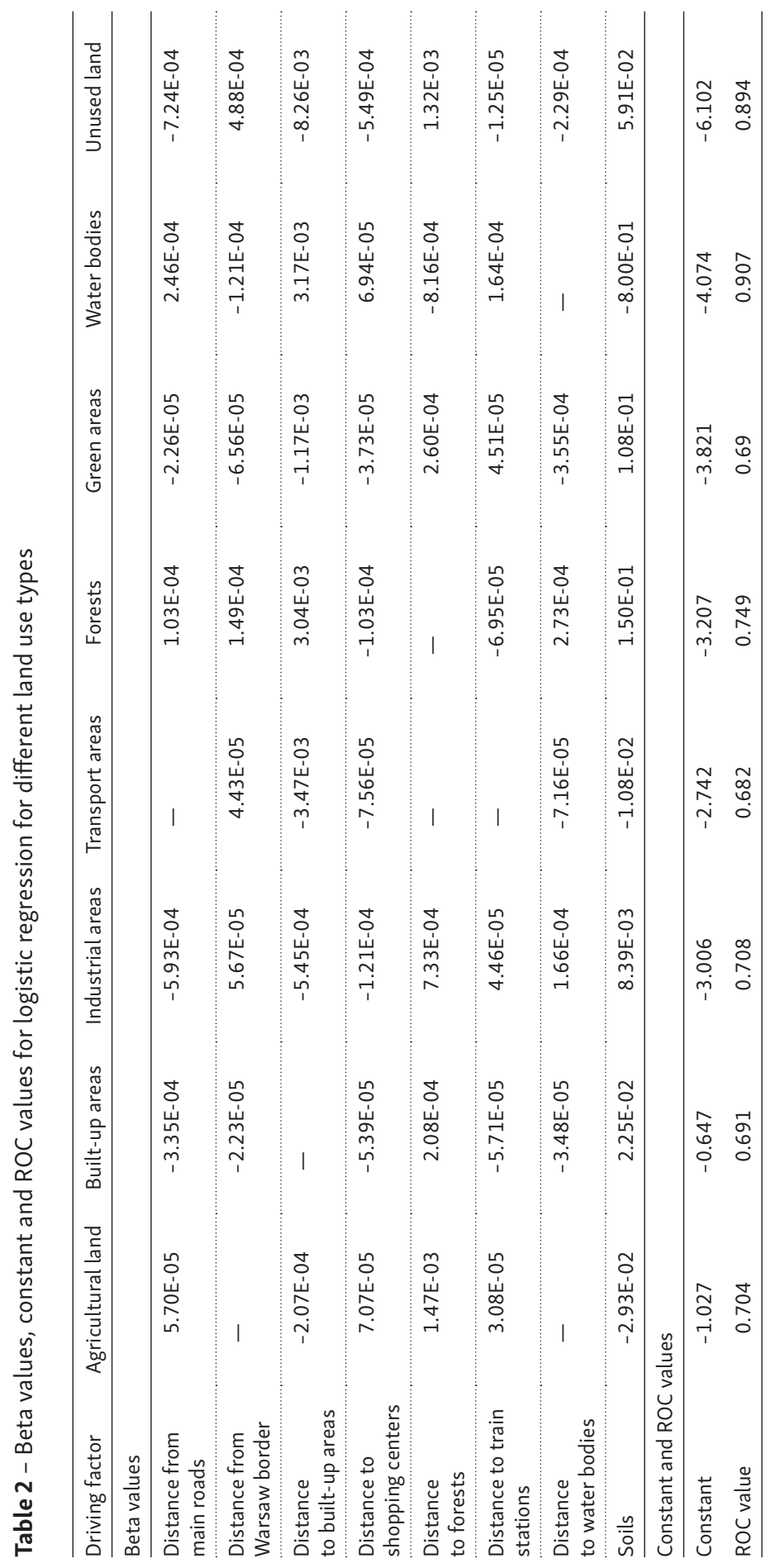


came in a form of relevance of the value of the coefficients of the logit model ( $\left.B^{\prime} s\right)$. By applying the logit regression, among the aforementioned factors, only those that have relevant access on categories of land use within the county area were selected. The aforementioned Beta values were then introduced as parameters into the Dyna-CLUE model.

Logit model fit measurement was determined on the basis of the ROC method (Pontius, Schneider 2001).

The research area included restricted areas which have not been taken into account as regions within which land use changes occur. These areas in the Piaseczno county include nature reserves with strict environment protection rules in place (restricted areas), along with the A spa zone area, within which a complete ban on creating any buildings remains in force. Warsaw Landscape Protection Zone within the $\mathrm{B}$ and $\mathrm{C}$ spa zones has also been taken into account. Within that area and within the range of the aforementioned zones, it is prohibited to localize new buildings. In the matrix, within which accepted transition of land use changes are defined, it was assumed that surface waters, forests, transport areas and the existing buildings may not be eradicated and replaced by other forms of land use. When defining the land-use demand, all scenarios assumed that more residential, commercial and industrial buildings are going to be created with decrement in the area of the agricultural areas and wastelands. The elasticity parameter assumes that agricultural fields are an usable area with high degree of elasticity, meaning that they can be easily transformed, adopting a variety of land use forms.

\subsection{Data used}

The spatial coverage data pertaining to the individual land use forms in the Piaseczno county has been based on the Urban Atlas (EEA 2014). For the purpose of modelling, the Urban Atlas land use map has been simplified and reclassified with a division into 8 classes being put into place. Water bodies, forests, built up areas, industrial areas, green areas, agricultural land, unused areas, transport areas (roads, railway) have been distinguished (Table 3, Fig. 3 ). Next, the vectorform land use map (shapefile format) has been converted into a rasterized form and then used to create 8 binary maps, each of which presented one of the land use forms (pixels representing the given land use form were ascribed with a value of 1). The terrain resolution has been adopted at a level of 30 meters which allowed to take into account the large fragmentation of the cadastral division and make analysis with great detail.

The driving factors maps were also initially prepared in a vector shapefile format, and then transformed into a raster format, with adoption of equivalent resolution (Fig. 4). Administrative division (NUTS 4, NUTS 5), river and main 
Table 3 - Look_up table of land use classes used in the model

\begin{tabular}{|c|c|}
\hline Urban Atlas nomenclature land use classes and vector data codes & $\begin{array}{l}\text { Land use classes applied } \\
\text { in the model }\end{array}$ \\
\hline Agricultural areas, semi-natural areas and wetlands (20000) & Agricultural area \\
\hline $\begin{array}{l}\text { Continuus Urban Fabic (11100) } \\
\text { Discontinuous Dense Urban Fabric (11210) } \\
\text { Discontinuous Medium Density Urban Fabric (11220), } \\
\text { Discontinuous Very Low Density Urban Fabric (11240) } \\
\text { Isolated Structures (11300), } \\
\text { Construction Sites (13300) }\end{array}$ & Built-up areas \\
\hline Industrial, comercial, public, military and private (12100) & Industrial areas \\
\hline $\begin{array}{l}\text { Railways and associated land (12230) } \\
\text { Roads and associated lands (12220) }\end{array}$ & Transport areas \\
\hline Forests $(30000)$ & Forests \\
\hline $\begin{array}{l}\text { Green urban areas (14100) } \\
\text { Sport and leasure facilities (14200) }\end{array}$ & Green areas \\
\hline Water (50000) & Water bodies \\
\hline Land without current use (13400) & Unused areas \\
\hline
\end{tabular}

road networks, train stations location were introduced in line with the General Geographic Database (GGDB) of Poland (Baza 2018). Locations of the shopping malls have been defined autonomously, on the basis of Google Maps data.

\subsection{Scenarios for the land use change}

For the purpose of modelling 2 land use change scenarios have been adopted, connecting the prospective land use changes with the expected population changes in the county, within the period of the upcoming 20 and 35 years. In both scenarios variants have been introduced depending on the anticipated forest treatment policy in the case of increased built up areas.

Scenarios, predicted until 2035: 1a. (basic) 2a. (pro-environmental).

Scenarios, predicted until 2050: 1b. (basic) 2b. (pro-environmental).

The predicted population increase for 2035 and 2050, estimated by the main statistical office in Poland (Prognoza 2011, Prognoza 2015), was used as the basis for calculating the demand for changes in land use. It was assumed that demographic "absorbency" within the areas of new settlement is going to be characterized by a value of 30 persons per each 10 thousand square meters. This value was accepted as suitable for the areas with detached houses, which, as it was assumed, are going to be the dominant form within the future arrangement of the buildings. This value is deliberately is smaller than value 40 persons/ha assumed in the subject literature for single-family housing in Poland (Kowalewski 2014), because it was assumed 
that in the future new residential areas will consist of the bigger parcels than now. At the same time, the authors, depending on the type of single-family housing, allow the spread of this indicator in the limit of 25-55 persons / 10 thousand $\mathrm{m}^{2}$.

Both scenarios assume that surface taken by the residential housing and increased area taken by this type of buildings constitute a result of the expected population growth within the county. Based on the prognoses, it was assumed that by 2035 the number of people in the Piaseczno county will increase by 55.3 thousand (Prognoza 2011, Prognoza 2015), which means that $1,846 \cdot 10^{4}$ square meters of ground would be needed to accommodate the residential buildings. Until the year 2050, the number of citizens is to go up by 72.7 thousand (Prognoza 2015), in comparison with the current population which, after proper calculations are made, means that $2,423 \cdot 10^{4}$ square meters of terrain would be required to create the new residential buildings. Moreover, adequately to the growth of population, expansion of the service-providing facilities- and industry-taken areas has been also taken into the equation. The element which creates a difference between those two scenarios is seen in the policy implemented towards the forest areas.

The scenario number one (basic) assumes that further expansion of the accommodation buildings is going to take place at a cost of the agricultural land and wastelands, and that the forested areas would remain unchanged. The second scenario (pro-environmental) assumes that increase of the surface taken by the housing estates is also going to take place at a cost of the agricultural lands and wastelands, however the afforestation process would also be a part of the events which would happen. Moreover, the latter scenario, during which the forested area would be expanded, is correlated to the proposal concerning the creation of two "green rings" around the city of Warsaw (Kozłowski 2006). The concept assuming that such rings would be created around 35 Polish cities, including Warsaw, is contained within the National Spatial Development Concept (Koncepcja 2012). Both scenarios assume then that expansion of the accommodation related buildings would take place without decrease of the forest area, while the second scenario sees the forest area expand even more. The scenario in question predicts that the forest cover would increase by $15 \%$, i.e. $3.3 \%$ of the total area of the county.

\section{Results}

The modelling results are high resolution maps of the expected land use in the Piaseczno county in the years 2035 and 2050, developed in the model according to assumed land use change scenarios (Fig. 5, 6). Both scenario 1 (basic) and 2 (pro-environmental) assume the growth of built-up areas; scenario 2 also assumes an increase in forest area (Table 4). 


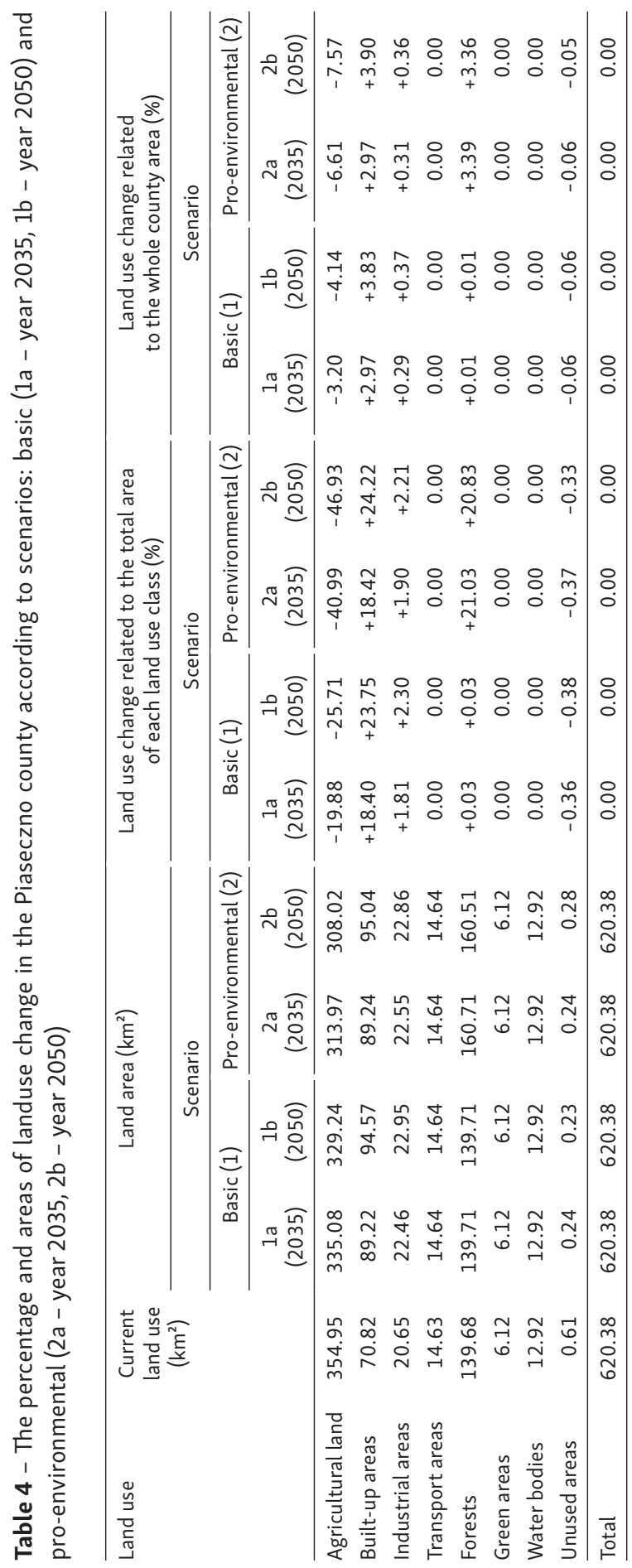




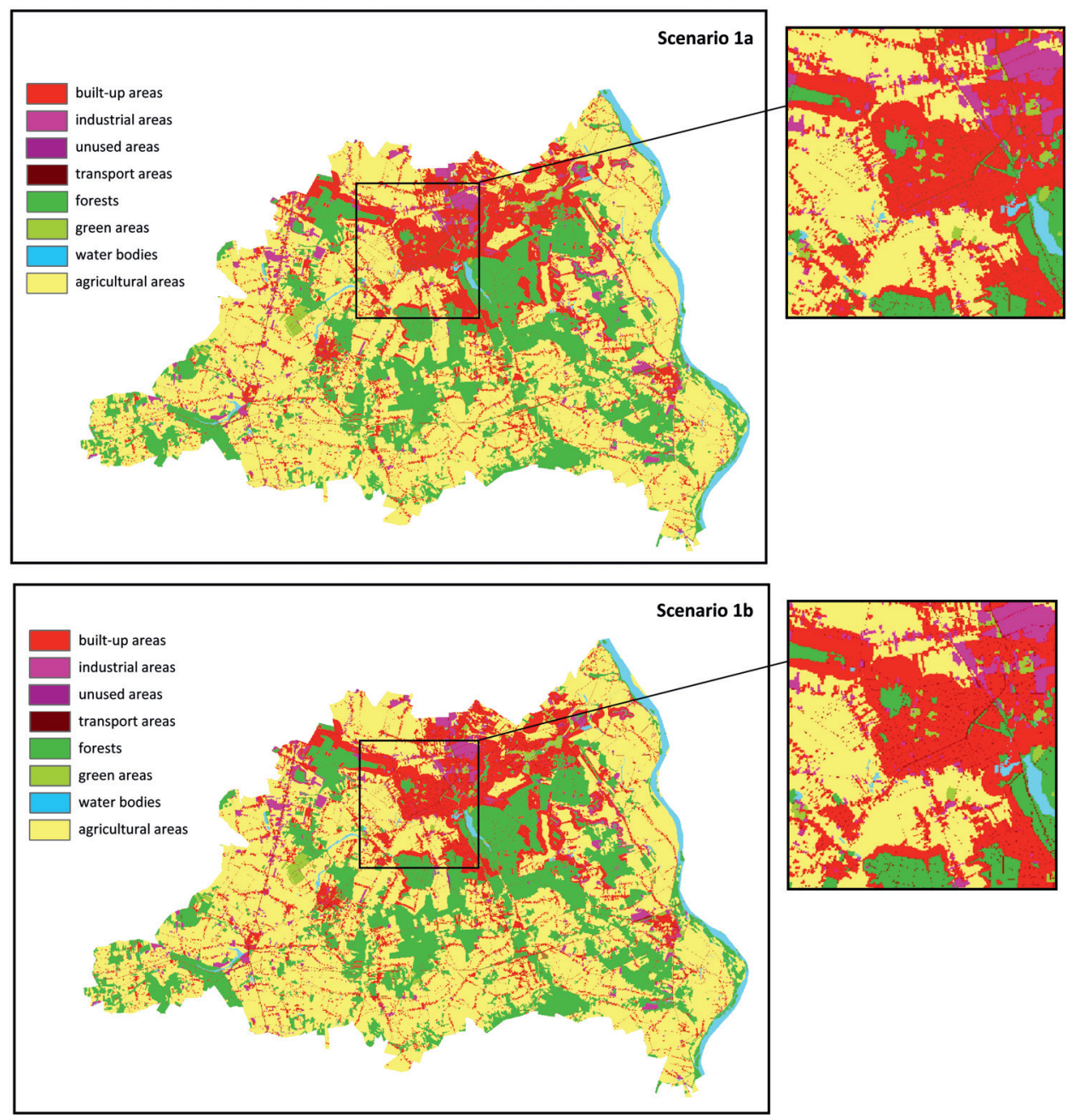

Fig. 5 - Land use maps according to basic scenarios (1a - year 2035, 1b - year 2050)

According to the assumptions adopted in both scenarios, based on population projections, the area occupied by development in the county will increase by $18 \mathrm{~km}^{2}$ (3.0\% of the county area) and by $24 \mathrm{~km}^{2}$ by 2050 (3.8\% of the county area). At present, it is $70 \mathrm{~km}^{2}$, thus increasing accordingly to $89.2 \mathrm{~km}^{2}$ in 2035 and $94.6 \mathrm{~km}^{2}$ in 2050 (Table 4). Scenarios $1 \mathrm{a}$ and $2 \mathrm{a}$ and $1 \mathrm{~b}$ and $2 \mathrm{~b}$ assume the same growth of built-up areas, but the results show little difference between the areas of the forecasted built-up areas calculated under these scenarios 1a and 2a and $1 \mathrm{~b}$ and $2 \mathrm{~b}$. This is due to the small deviations allowed in the model between the projected surface area of a given form of surface use and the assumed demand 


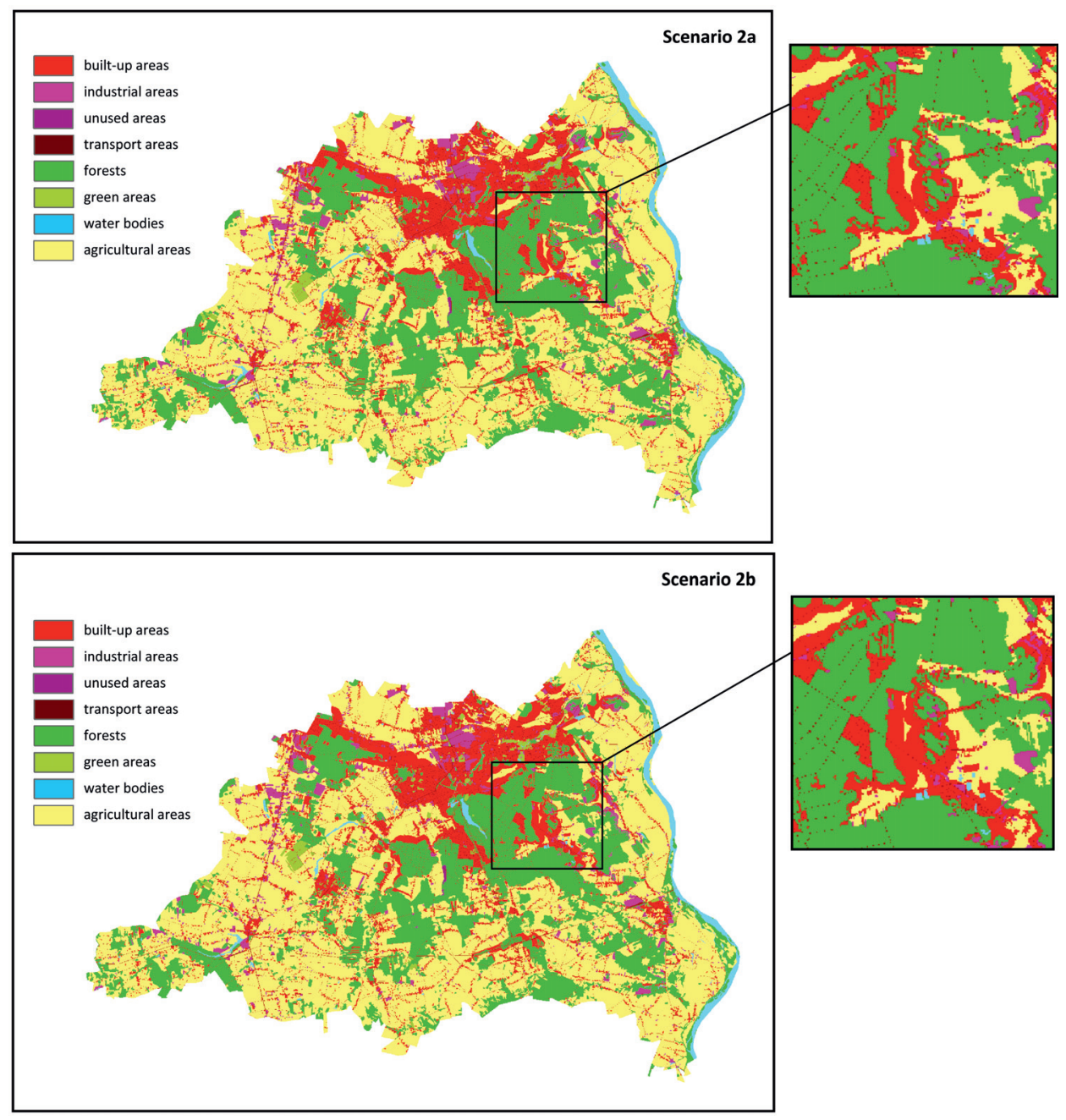

Fig. 6 - Land use maps according to pro-environmental scenarios ( $2 a$ - year 2035, 2b - year 2050)

for this use class during its allocation; this deviation is also possible for other usage classes.

At this point it should be emphasized that the areas occupied by the various land use types throughout the research area were determined at the stage of identifying the demand model parameters and thus did not result from modelling. The result of modelling is the hypothetical spatial distribution of particular forms of land use, including the main interest, built-up areas and calculated on the basis of the result maps, the percentage structure of land use in individual municipalities. It should also be noted that due to the small percentage of land use change, 
the maximum land use change rate is $-7.57 \%$ for agricultural land (scenario $2 \mathrm{~b}$ ) and for residential housing from $+3.8 \%$ to $+3.9 \%$ (scenarios $1 b$, $2 \mathrm{~b}$; Table 4 ). These changes are discreetly expressed on the maps and are difficult to grasp visually on a small scale map, therefore, the selected map fragment is shown enlarged (Fig. 5, 6). Assumed changes of surface area occupied by industrial buildings are positive but not large - regardless of the scenario they do not exceed $+1 \%$. In all scenarios, there is a decrease in unused land (about $-0.4 \%$ of all unused areas, $-0.06 \%$ of the area of the county), but it is worth noting that they occupy a very small area $\left(0.61 \mathrm{~km}^{2}\right)$. Scenarios $2 \mathrm{a}$ and $2 \mathrm{~b}$ assume forest area growth of about $20 \%$ (3.4\% of the county). Currently, the forests cover $139.7 \mathrm{~km}^{2}$ of surface area, so their predicted area (both in 2035 and 2050) is $161 \mathrm{~km}^{2}$ (Table 4). The areas occupied by green areas, communication and surface water are forecasted to remain stable and will not be allocated.

According to both scenarios, the new residential development will be almost entirely located in the northern part of the county in three municipalities: Piaseczno, Lesznowola and Konstancin-Jeziorna (Figs. 5, 6). The housing development is forecast to grow the most in an area of about $15 \mathrm{~km}$ wide adjacent to the southern border of Warsaw, with the most housing development areas coming within $5-7 \mathrm{~km}$.

The result maps show that the new housing developments, apart from being located in areas that are as close as possible to the borders of Warsaw, will be located primarily at the same time as the model predicts within close proximity to forest complexes, water reservoirs and nearby existing residentials. It will grow ring around these areas, leading to the expansion of already existing housing estates. As a result of progressive ring development, building enclaves will be merged, resulting in the development and expansion of the W-E belt of continuous residential areas at a distance of about $10 \mathrm{~km}$ from Warsaw. The anticipated appearance of buildings in the immediate vicinity of forests is a serious phenomenon that has already occurred and was highlighted by Mantey (2009a) and Degórska, Deręgowska (2008).

A significant part of the new development will be located in the Piaseczno municipality, which is already the most urbanized municipality in the county (housing in the municipality is currently occupied by $26 \mathrm{~km}^{2}$, i.e. $21 \%$; Fig. 7, Tables 1, 3, 4).

The new development will also appear in areas located further from the borders of Warsaw - at a distance of about $25 \mathrm{~km}$, on the border of the municipalities of Prażmów and Góra Kalwaria, near the forest complexes (Fig. 6, 7) but in a much smaller dimension. Scenarios $2 \mathrm{a}$ and $2 \mathrm{~b}$, assuming increasing forest areas, transform the forests into agricultural areas located in the immediate vicinity of already existing forests. This applies to forests in the municipalities located in the north of the county and to the central part of it (Fig. 6, 7). 


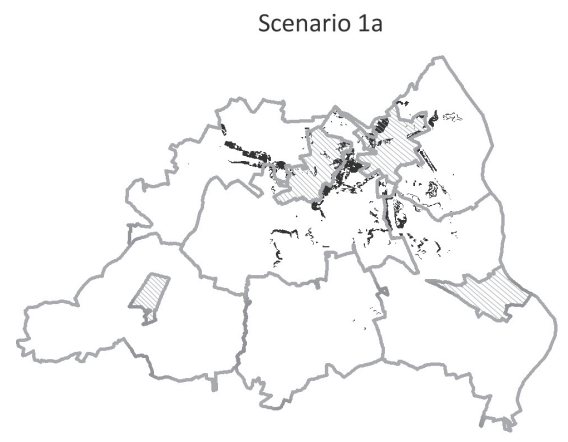

Scenario $1 b$
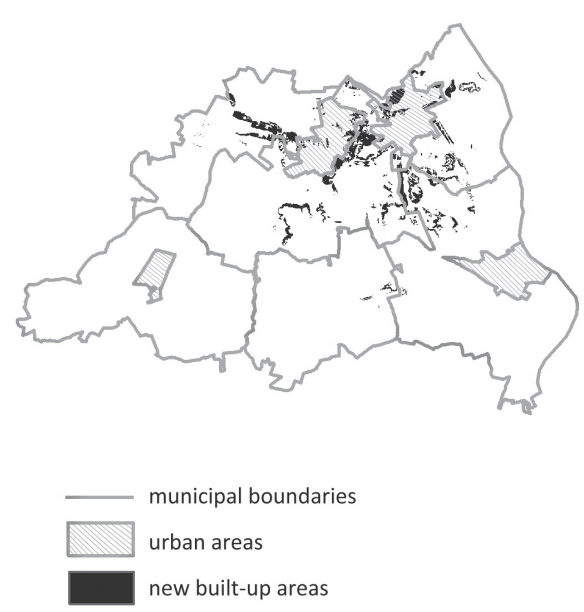

Scenario $2 \mathrm{a}$

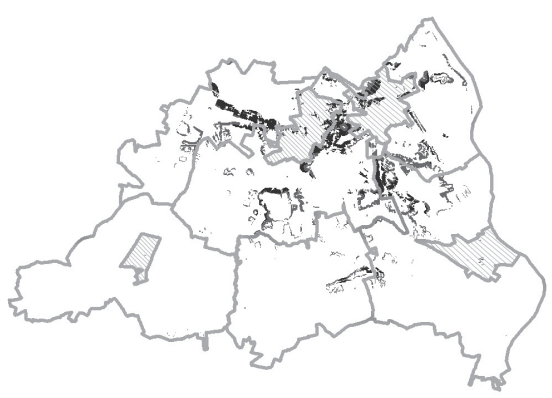

Scenario $2 b$

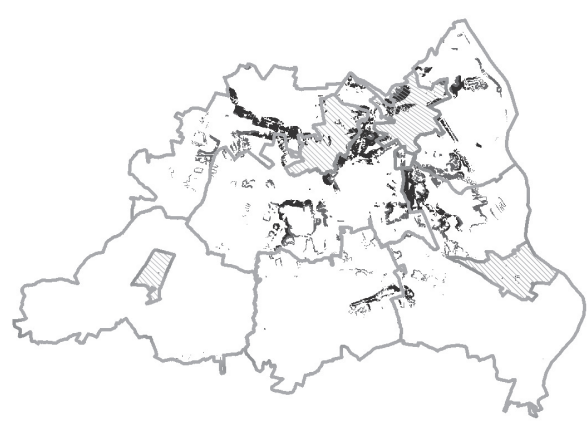

$\square$ municipal boundaries
urban areas
new built-up areas
new forests

Fig. 7 - New built-up areas and new forests according to the land use change scenarios la (basic, year 2035), 1b (basic, year 2050), 2a (pro-environmental, year 2035), 2b (pro-environmental, year 2050)

The loss of area currently occupied by agricultural land $\left(355 \mathrm{~km}^{2}\right)$ exceeds $40 \%$ in these scenarios (scenario $2 \mathrm{a}:-41.0 \%$, scenario $2 \mathrm{~b}:-46.9 \%$; $-6.6 \%$ and $-7.6 \%$ respectively to the area of the whole county - Table 4). Forests, similar to the buildings, according to the forecast model will not appear in the form of new forest complexes, but in the form of belts in already existing forests.

According to model estimates, the largest absolute growth of built-up area will occur in two municipalities: Piaseczno and Konstancin-Jeziorna. The area of residential development in 2035 in Piaseczno municipality is expected to increase by $7.9 \mathrm{~km}^{2}$ (scenario $1 \mathrm{a}-$ basic) and by $9.7 \mathrm{~km}^{2}$ in 2050 (scenario $1 \mathrm{~b}-$ basic; Table 5). 
Table 5 - Changes of areas of built up areas and forests in the municipalities of the Piaseczno county according to different scenarios: basic (1a - year 2035, 1b - year 2050) and pro-environmetal (2a year 2035, 2b - year 2050). Changes in the area of particular classes of land use are expressed in absolute units $\left(\mathrm{km}^{2}\right)$ and referred to the total area of a given class and the total area of an administrative unit.

\begin{tabular}{|c|c|c|c|c|c|c|}
\hline \multirow{2}{*}{$\begin{array}{l}\text { Municipality } \\
\text { Built-up areas }\end{array}$} & \multicolumn{2}{|c|}{ Area change $\left(\mathrm{km}^{2}\right)$} & \multicolumn{2}{|c|}{$\begin{array}{c}\text { Change }(\%) \text { of particular land } \\
\text { use category }\end{array}$} & \multicolumn{2}{|c|}{$\begin{array}{l}\text { Change }(\%) \text { of particular land } \\
\text { use category in regard to the } \\
\text { administrative unit area }\end{array}$} \\
\hline & & & & & & \\
\hline & $\begin{array}{l}\text { Basic scenario } \\
\text { 1a }(2035)\end{array}$ & $\begin{array}{l}\text { Basic scenario } \\
1 \mathrm{~b}(2050)\end{array}$ & $\begin{array}{l}\text { Basic Scenario } \\
\text { 1a }(2035)\end{array}$ & $\begin{array}{l}\text { Basic Scenario } \\
\text { 1b }(2050)\end{array}$ & $\begin{array}{c}\text { Basic Scenario } \\
\text { 1a }(2035)\end{array}$ & $\begin{array}{c}\text { Basic Scenario } \\
\text { 1b }(2050)\end{array}$ \\
\hline Lesznowola & +2.91 & +3.53 & 27.67 & 33.64 & 4.20 & 5.10 \\
\hline Prażmów & +0.06 & +0.37 & 0.85 & 5.13 & 0.07 & 0.43 \\
\hline Tarczyn & 0.00 & +0.00 & 0.00 & 0.00 & 0.00 & 0.00 \\
\hline Góra Kalwaria & +2.43 & +3.66 & 26.44 & 39.75 & 1.69 & 2.54 \\
\hline Piaseczno & +7.92 & +9.66 & 30.47 & 37.15 & 6.18 & 7.54 \\
\hline Konstancin & +5.08 & +6.54 & 47.42 & 61.03 & 6.47 & 8.33 \\
\hline \multirow[t]{2}{*}{ Total area } & +18.40 & +23.75 & 25.98 & 33.54 & 2.97 & 3.83 \\
\hline & $\begin{array}{l}\text { Pro- } \\
\text { environmetal } \\
\text { scenario 2a } \\
(2035)\end{array}$ & $\begin{array}{c}\text { Pro- } \\
\text { environmetal } \\
\text { scenario } 2 b \\
(2050)\end{array}$ & $\begin{array}{l}\text { Pro- } \\
\text { environmetal } \\
\text { scenario 2a } \\
(2035)\end{array}$ & $\begin{array}{c}\text { Pro- } \\
\text { environmetal } \\
\text { scenario } 2 b \\
(2050)\end{array}$ & $\begin{array}{c}\text { Pro- } \\
\text { environmetal } \\
\text { scenario 2a } \\
(2035)\end{array}$ & $\begin{array}{c}\text { Pro- } \\
\text { environmetal } \\
\text { scenario } 2 b \\
(2050)\end{array}$ \\
\hline Lesznowola & +3.60 & +4.35 & 34.25 & 41.41 & 5.19 & 6.28 \\
\hline Prażmów & +0.45 & +0.89 & 6.25 & 12.34 & 0.52 & 1.03 \\
\hline Tarczyn & 0.00 & 0.00 & 0.00 & 0.00 & 0.00 & 0.00 \\
\hline Góra Kalwaria & +2.83 & +4.12 & 30.77 & 44.71 & 1.97 & 2.86 \\
\hline Piaseczno & +7.56 & +9.63 & 29.09 & 37.06 & 5.90 & 7.52 \\
\hline Konstancin & +3.98 & +5.24 & 37.18 & 48.89 & 5.07 & 6.67 \\
\hline Total area & +18.42 & +24.22 & 26.01 & 34.20 & 2.97 & 3.90 \\
\hline
\end{tabular}

Forests

\begin{tabular}{|c|c|c|c|c|c|c|}
\hline & $\begin{array}{c}\text { Pro- } \\
\text { environmetal } \\
\text { scenario 2a } \\
(2035)\end{array}$ & $\begin{array}{c}\text { Pro- } \\
\text { environmetal } \\
\text { scenario } 2 b \\
(2050)\end{array}$ & $\begin{array}{c}\text { Pro- } \\
\text { environmetal } \\
\text { scenario 2a } \\
(2035)\end{array}$ & $\begin{array}{c}\text { Pro- } \\
\text { environmetal } \\
\text { scenario } 2 b \\
(2050)\end{array}$ & $\begin{array}{c}\text { Pro- } \\
\text { environmetal } \\
\text { scenario } 2 a \\
(2035)\end{array}$ & $\begin{array}{c}\text { Pro- } \\
\text { environmetal } \\
\text { scenario } 2 \mathrm{~b} \\
(2050)\end{array}$ \\
\hline Lesznowola & +3.04 & +3.04 & 31.95 & 31.98 & 4.39 & 4.40 \\
\hline Prażmów & +1.40 & +1.68 & 5.97 & 7.18 & 1.61 & 1.94 \\
\hline Tarczyn & +0.05 & +0.05 & 0.21 & 0.21 & 0.04 & 0.04 \\
\hline Góra Kalwaria & +4.65 & +4.69 & 12.85 & 12.95 & 3.23 & 3.26 \\
\hline Piaseczno & +6.67 & +6.41 & 18.40 & 17.68 & 5.21 & 5.00 \\
\hline Konstancin & +5.22 & +4.96 & 44.76 & 42.53 & 6.65 & 6.32 \\
\hline Total area & +21.03 & +20.83 & 15.06 & 14.92 & 3.39 & 3.36 \\
\hline
\end{tabular}


It is respectively an increase of $30 \%$ and $37 \%$ in relation to the area of development in the municipality and $6.18 \%$ and $7.54 \%$ of the whole area of the municipality (Table 5). In the municipality of Konstancin-Jeziorna the increase of area of housing development is slightly smaller $\left(+5.1 \mathrm{~km}^{2}\right.$ in 2035 and $+6.54 \mathrm{~km}^{2}$ in 2050 according to the basic scenario), but it constitute a greater burden for the municipality than in Piaseczno administrative unit $(+6.5 \%$ in 2035 and $+8.33 \%$ of the area by the basic scenario; Table 5). Built-up area in 2050, due to the area currently occupied, will increase by $47 \%$ in 2035 and $61 \%$ in 2050 . Slightly lower values, but still high compared to other land use classes, characterize the projected areas of development according to the pro-environmental scenario.

The municipality in which according to forecasts will not be located until 2050 new housing development, is located in the south-west part of the county in Tarczyn municipality. The decisive factor is the remoteness from Warsaw. New buildings in this municipality do not appear in any of the scenarios. In two other municipalities located alongside the Tarczyn municipality to the south, small clusters of new buildings will appear, widening between the years 2035-2050 (Fig. 7).

\section{Conclusions}

In conclusion this study makes it possible to draw the following general conclusions. In Polish literature, there is still little work devoted to modelling land use changes, including urban sprawl.

The Dyna-CLUE model, due to its complexity, fulfilled its task, because it allowed for the inclusion of many different factors affecting the land use process as a result of the urban sprawl.

The use of a high level of input materials allowed for a large spatial resolution of the research. Application of the model let indicate areas which may be in the future subject to the greatest urban pressure (under the assumptions made). According to the modelling results the greatest urban pressure due to the projected further population growth in the Piaseczno county in the time horizon of 2035 and 2050 should still be expected in the municipalities adjacent to the capital, especially in the most urbanized Piaseczno and Konstancin-Jeziorna municipalities. Expected further development of the continuous built up belt within a few kilometers south of Warsaw, confirms its prediction of its role in the development strategy of the Piaseczyński county (Strategia 2002).

The high pressure of residential development in the Konstancin-Jeziorna municipality predicted by the model, should be particularly taken up by the local authorities, as this area requires particular attention due to the protected nature resources and the location of the spa. 


\section{References}

BABAEI AgDAM, F., EBRAHEEMZADE, ASMin, H. (2012): Modeling Agricultural and Arid Land use Changes Into Built-up in Ardail Urban Region Using CLUE-S Model. Geography and Development, 26, 5-8, http://www.sid.ir/en/VEWSSID/J_pdf/98920122602.pdf (16. 6. 2017).

BAŃSKI, J. (2007): Przemiany funkcjonalno-przestrzenne terenów wiejskich - diagnoza, rekomendacje dla KPZK i dyskusja, https://astrofizyka.files.wordpress.com/2016/09/przemianyterenc3b3w-wiejskich.pdf (16.6.2017).

BATISANI, N., YARNAL, B. (2009): Uncertainty awareness in urban sprawl simulations: Lessons from a small US metropolitan region. Land Use Policy, 26, 178-185.

Baza (2018): Baza danych Obiektów Ogólnogeograficznych. Centralny Ośrodek Dokumentacji Geodezyjnej i Kartograficznej. http://www.codgik.gov.pl/index.php/darmowe-dane/bdo250gis.html (16. 6. 2017).

BEIM, M. (2007): Modelowanie procesu suburbanizacji w aglomeracji poznańskiej z wykorzystaniem sztucznych sieci neuronowych i automatów komórkowych. PhD Thesis. Uniwersytet im. Adama Mickiewicza w Poznaniu, Poznan.

BRIASSOULIS, H. (2009): Factors influencing land-use and land-cover change. In: Verheye, W. (ed.): Land use, land cover and soil sciences, vol. 1, Encyclopedia of Life Support Systems (EOLSS), 126-146.

CHU, H.J., LIN, Y.P., WU, C.F. (2010): Forecasting space-time land use change in the Paochiao watershed of Taiwan using demand estimation and empirical simulation approaches. Lect. Notes Comput. Sci. (including Subser. Lect. Notes Artif. Intell. Lect. Notes Bioinformatics) 6016 LNCS, 116-130.

DEGÓRSKA, B., DERĘGOWSKA, A. (2008): Zmiany krajobrazu obszaru metropolitalnego Warszawy na przełomie XX i XXI wieku. Atlas Warszawy, 10, IGiPZ PAN, Warsaw.

EEA (2014): Urban Atlas. https://www.eea.europa.eu/data-and-maps/data/urban-atlas (16. 6. 2017).

GROCHOWSKI, M. (2009): Samorząd terytorialny a rozwój zrównoważony obszarów metropolitalnych. Mazowsze Studia Regionalne, 2, 73-88.

Koncepcja (2012): Koncepcja Przestrzennego Zagospodarowania Kraju 2030, http://mr.bip.gov. pl/strategie-rozwoj-regionalny/17847_strategie.html (16.6.2017).

KORCELLI, P., GROCHOWSKI, M., KOZUBEK, E., KORCELLI-OLEJNICZAK, E., WERNER, P.A. (2012): Development of urban-rural regions: from European to local perspective. Institute of Geography and Spatial Organization, Polish Academy of Sciences, 14.

KOWALEWSKI, A. (2014): Raport o ekonomicznych stratach i społecznych kosztach niekontrolowanej urbanizacji w Polsce. Appendix 3. IGPZ PAN, http://www.kongresbudownictwa. pl/pliki/konferencja\%20kongresu\%202014.06.30.pdf (16. 6. 2017).

KOZŁOWSKI, S. (2006): Propozycje zielonych pierścieni w obszarze metropolitalnym Warszawy. In: Kozłowski, S. (ed.): Żywiołowe rozprzestrzenianie się miast. Narastający problem aglomeracji miejskich w Polsce, Komitet “Człowiek i Środowisko”, PAN, Białystok - Lublin -Warszawa, 86-95.

LIN, Y.P., LIN, Y.B., WANG, Y.T., HONG, N.M. (2008): Monitoring and Predicting Land-use Changes and the Hydrology of the Urbanized Paochiao Watershed in Taiwan Using Remote Sensing Data, Urban Growth Models and a Hydrological Model. Sensors 8, 658-680.

LITWIŃSKA, E. (2010): Modelowanie struktur metropolitalnych w aspekcie zjawiska Urban Sprawl. Architekture, Technical Transactions, 107, 3, 139-148. 
LIU, M., HU, Y., CHANG, Y., HE, X., ZHANG, W. (2009): Land use and land cover change analysis and prediction in the upper reaches of the Minjiang river, China. Environmental Management, 43, 899-907.

MANTEY, D. (2013a): Gmina jako miejsce identyfikacji - raport z badań w podwarszawskiej gminie Piaseczno. Mazowsze Studia Regionalne, 13, 47-74.

MANTEY, D. (2013b): Pułapka suburbanizacji, czyli o planach migracyjnych młodych piaseczan. Przegląd Geograficzny, 85, 2, 271-289.

MANTEY, D. (2009a): Żywiołowość procesów przestrzennych. Prace Geograficzne, 42, 153-173.

MANTEY, D. (2009b): Żywiołowe rozpraszanie się funkcji mieszkaniowych Warszawy przykład osiedli podwarszawskich, Prace Geograficzne, 121, 223-235.

MANTEY, D. (2009c): Żywiołowość lokalizacji osiedli mieszkaniowych na terenach wiejskich obszaru metropolitalnego Warszawy. University of Warsaw.

POŁAWSKI, Z. (2009): Zmiany użytkowania ziemi w Polsce w ostatnich dwóch stuleciach. Teledetekcja Środowiska, 42, 69-82.

PONTIUS, R.G., SCHNEIDER, L.C. (2001): Land use change model validation by an ROC method for the Ipswich watershed. Agric. Ecosyst. Environ., 85, 239-248.

PRICE, B., KIENAST, F., SEIDL, I., GINZLER, C., VERBURG, P.H., BOLLIGER, J. (2015): Future landscapes of Switzerland: Risk areas for urbanisation and land abandonment. Appl. Geogr. $57,32-41$.

Prognoza (2011): Prognoza demograficzna dla Mazowsza do roku 2035. Mazowiecki Ośrodek Badań Regionalnych. Warszawa 2011.

Prognoza (2015): Prognoza ludności dla województwa mazowieckiego na lata 2014-2050, https:// warszawa.stat.gov.pl/publikacje-i-foldery/ludnosc/prognoza-ludnosci-dla-wojewodztwamazowieckiego-na-lata-20142050,6,1.html (16.6. 2017).

ROUX, A., AUGUSTIJN, P.W.M. (2015): Quantifying the spatial implications of future land use policies in South Africa. South African Geographical Journal, 99, 1, 29-51.

Strategia (2002): Strategia zrównoważonego rozwoju powiatu piaseczyńskiego. Część I. Diagnoza. IGPM, Warszawa.

ŚLESZYNSKI, P. (2014): Przemiany społeczno-demograficzne województwa mazowieckiego w latach 1990-2013. Trendy rozwojowe Mazowsza nr 15. Warszawa.

ŚWIDERSKI, A. (2007): Geoinformacyjne modele prognozowania użytkowania ziemi. Wydział Nauk Geograficznych i Geologicznych. UAM, Poznań.

VELDKAMP, A., FRESCO, L.O. (1996): CLUE: a conceptual model to study the Conversion of Land Use and its Effects. Ecol. Modell, 85, 253-270.

VERBURG, P.H. (2010): CLUE Modeling Framework. Course material. Vrije Universiteit Amsterdam, Institute for Environmental Studies, http://www.ivm.vu.nl/en/Images/Exercises_tcm234-284019.pdf (16.6.2017).

VERBURG, P.H., DE KONING, G.H.J., KOK, K., VELDKAMP, A., BOUMA, J. (1999): Spatial explicit allocation procedure for modelling the pattern of land use change based upon actual land use, Ecological Modelling 116, 45-61.

VERBURG, P.H., OVERMARS, K.P. (2009): Combining top-down and bottom-up dynamics in land use modeling: Exploring the future of abandoned farmlands in Europe with the DynaCLUE model. Landscape Ecology, 24, 1167-1181.

VERBURG, P.H., OVERMARS, K.P., HUIGEN, M.G.A., DE GROOT, W.T., VELDKAMP, A. (2006a): Analysis of the effects of land use change on protected areas in the Philippines. Applied Geography, 26, 153-173. 
VERBURG, P.H., SCHULP, C.J.E., WITTE, N., VELDKAMP, A. (2006b): Downscaling of land use change scenarios to assess the dynamics of European landscapes. Agriculture, ecosystems and environment, 114, 1, 39-56.

VERBURG, P.H, VAN DE STEEG J., SCHULP, N. (2005): Manual for the CLUE-Kenya application. http://www.trajectories.org/download/CLUE_manual.pdf (16.6.2017).

VERBURG, P.H., SOEPBOER, W., VELDKAMP, A., LIMPIADA, R., ESPALDON, V., MASTURA, S.S.A. (2002): Modeling the spatial dynamics of regional land use: The CLUE-S model. Environ. Manage. 30, 391-405.

VERBURG, P.H., VAN BERKEL, D.B., VAN DOORN, A.M., VAN EUPEN, M., VAN DEN HEILIGENBERG, H.A.R.M. (2010): Trajectories of land use change in Europe: A model-based exploration of rural futures. Landscape Ecol, 25, 217-232.

WERNER, P.A. (2012): Neighbourhood coefficients of cellular automata for research on land use changes with map algebra. Misc. Geogr. - Reg. Stud. Dev., 16, 57-63.

WERNER, P.A. (2009): Application of celluclar automata and map algebra in studies of land use changes. The neighborhood coefficients method ${ }^{\circledR}$. Geoinformatica Pol. 9, 7-20.

WERNER, P.A. (2006): Simulation of changes of the Warsaw Urban Area 1969-2023. Application of cellular automata. Misc. Geogr., 12, 329-335.

WERNER, P.A. (2005): Symulacja zmian zasięgu obszaru zurbanizowanego aglomeracji Warszawy (eksperyment zastosowania automatów komórkowych). Biul. Kom. Przestrz. Zagospod. Kraju. PAN, 219, 212-219.

WERNER, P.A., KORCELLI, P., KOZUBEK, E. (2014). Population Potential as a Modulator of Land use Changes in Poland'S Metropolitan Areas. Quaestiones Geographicae, 33, 2, http:// doi.org/10.2478/quageo-2014-0014 (16.6.2017).

WERNER, P.A., KOZUBEK, E. (2011): Visualisation of land use change in Poland based on neigborhood analysis (1990-2006). In: Ruas, A. (ed.): Proceedings of the $25^{\text {th }}$ International Cartographic Conference, Paris, France, 3-8 July 2011, https:/icaci.org/files/documents/ ICC_proceedings/ICC2011/ (16.2.2019).

XAVIER, J. (2013): Modelling urban expansion spatial patterns: a methodological approach using cellular automata 1-10, https://fenix.tecnico.ulisboa.pt/downloadFile/395145922557/ EXTENDED\%20ABSTRACT_JX.pdf (16.6.2017).

XU, L., LI, Z., SONG, H., YIN, H. (2013): Land-use planning for urban sprawl based on the CLUE-S model: A Case study of Guangzhou, China. Entropy 15, 3490-3506.

Zaktualizowana koncepcja (2005): Zaktualizowana koncepcja przestrzennego zagospodarowania kraju. Warsaw 2005.

ZHENG, H.W., SHEN, G.Q., WANG, H., HONG, J. (2015): Simulating land use change in urban renewal areas: A case study in Hong Kong. Habitat Int. 46, 23-34. 